\title{
Nutritional and physical characteristics of noodles incorporated with green seaweed (Ulva reticulata) and fish (Pangasianodon hypophthalmus) mince
}

\author{
JESMI DEBBARMA, P. VIJI, B. M. RAO AND M. M. PRASAD* \\ Visakhapatnam Research Centre of ICAR-Central Institute of Fisheries Technology, Visakhapatnam - 530003 \\ Andhra Pradesh, India \\ ${ }^{2}$ ICAR-Central Institute of Fisheries Technology, Kochi - 682 029, kerala, India \\ e-mail: jessmi.cife@gmail.com
}

\begin{abstract}
Nutritional and physical properties of noodles incorporated with green seaweed (Ulva reticulata) puree and fish (Pangasionodon hypophthalmus) mince were evaluated. Four lots of noodles were prepared using different formulations viz., control noodle without adding seaweed puree or fish meat (C); noodle with $20 \%$ cooked pangasius fish meat (T1), noodles with $20 \%$ seaweed puree (T2) and noodles with $10 \%$ seaweed puree and $10 \%$ cooked pangasius fish meat (T3). Proximate composition, cooking properties, textural and sensory qualities of noodles were assessed. Results indicated that addition of green seaweed puree increased the crude fibre content of noodles. Crude fibre content was higher in T2 $(2.62 \pm 0.18 \%)$ followed by T3 $(1.71 \pm 0.06 \%)$. Cooking time for noodles varied between $6.80 \pm 0.71$ and $9.15 \pm 0.21 \mathrm{~min}$ and cooking loss was significantly $(\mathrm{p}<0.05)$ higher for noodles with $20 \%$ seaweed puree. Significantly higher water absorption was noticed in noodles with $20 \%$ green seaweed puree, which led to softer and spongier textural intensities of the noodles. Although T2 showed lower score for colour values, its overall score for flavour and taste was higher compared to control and other treatments. The results indicate that incorporation of green seaweed puree in noodles has positively influenced the flavour as well as fibre content and hence, it can be used to enrich the fibre content of noodles.
\end{abstract}

Keywords: Crude fibre, Fish mince, Green seaweed, Noodles, Pangasianodon hypophthalmus, Ulva reticulata

\section{Introduction}

In recent years, use of seaweeds as a functional or nutritional ingredient in food products is gaining importance among the researchers worldwide. Seaweeds have been widely consumed as food since ancient time in Asian countries including China, Japan and Korea. Edible seaweeds are rich in polysaccharides, proteins, minerals and vitamins but low in lipid content (1-3\% algal dry weight) with high amount of certain long chain polyunsaturated fatty acids (Fleurence, 1999; Ruperez et al., 2002; Dawczynski et al., 2007; Bocanegra et al., 2009). They also act as antioxidants and antimicrobial compounds (Kuda et al., 2005; Gupta et al., 2010). The potential of seaweed as a source of iron, iodine, dietary fibre and as salt replacer has been demonstrated (Goni et al., 2000; Chang and Wu, 2008; Gupta and Abu-Ghannam, 2011).

Noodles are popular food products worldwide, especially in South-east Asia. According to the report by World Instant Noodle Association (2014), the annual production of noodles was 105.65 billion packs in 2013 and is increasing at a rate of 3\% per year since 2010 . Even though, noodles are a popular fast food item, those available in the market generally have low nutritional value in terms of dietary fibre, minerals and vitamins which are lost during wheat flour refinement (Ojure and Quadri, 2012). Hence, recently, the manufacturers as well as researchers are constantly focusing on improving the nutritional quality of noodles (Verardo et al., 2009; Vijayakumar, 2010; Kim et al., 2014). Addition of seaweed to noodles can be a promising technology for enriching its dietary fibre and mineral content as well as for promoting seaweed as a food component in places where seaweed consumption is unpopular. Indian waters are rich sources of various edible seaweeds; however, its use has been traditionally limited to extraction of phycocolloids and production of fertilisers. Hence it is necessary to explore the possibilities of use of seaweed as a food ingredient in frequently consumed and self stable products like noodles.

Ulva reticulata is a green seaweed that grows abundantly in Indian marine waters but there has been only very little exploitation of this seaweed species. Pangasius (Pangasionodon hypophthalmus) meat has high nutritive qualities, excellent sensory properties and is amenable for development of convenience products (Silva et al., 2002; Rao et al., 2013). However, fish meat has negligible content of dietary fibre. The present study was 
envisaged to nutritionally enrich noodles by incorporating green seaweed and pangasius fish mince, either alone or in combination and to evaluate the nutritional and physical properties of the noodles developed.

\section{Materials and methods}

\section{Preparation of noodles}

$U$. reticulata was collected from Visakhapatnam Coast, Andhra Pradesh. Seaweed was handpicked, washed thoroughly with potable water to remove epiphytes and foreign particles and then ground to make seaweed puree. $P$. hypophthalmus was procured from the local fish market and mince was prepared in laboratory under hygienic conditions and was cooked by steaming for $15 \mathrm{~min}$. Other ingredients for noodles were procured locally.

Four lots of noodles were prepared using different formulations (Table 1) viz., control containing noodle without seaweed puree or fish meat (C); noodles with $20 \%$ cooked pangasius fish meat (T1), noodles with $20 \%$ green seaweed puree (T2) and noodles with $10 \%$ green seaweed puree $+10 \%$ cooked pangasius fish meat (T3). All the ingredients were mixed lot-wise to make dough and the dough was sheeted, rolled and passed through cutting blades of commercial noodles making machine to obtain noodle strands of desired width. Noodles were steam cooked and dried at $50^{\circ} \mathrm{C}$ in mechanical dryer for bringing down the moisture content below $10 \%$.

Table 1. Formulation of dry noodles with and without green sea weed puree

\begin{tabular}{lllll}
\hline \multirow{2}{*}{ Ingredients } & \multicolumn{5}{c}{ Type of noodles } \\
\cline { 2 - 6 } & $\mathrm{C}$ & $\mathrm{T} 1$ & $\mathrm{~T} 2$ & $\mathrm{~T} 3$ \\
\hline Refined wheat flour (\%) & 82 & 62 & 62 & 62 \\
Corn flour (\%) & 5 & 5 & 5 & 5 \\
Tapioca starch (\%) & 10 & 10 & 10 & 10 \\
Salt (\%) & 3 & 3 & 3 & 3 \\
Cooked Pangasius fish meat (\%) & - & 20 & - & 10 \\
Green-seaweed (U. reticulata) puree (\%) & - & - & 20 & 10 \\
Water (ml per 100 g dry noodle mix) & 40 & 30 & 30 & 30 \\
\hline
\end{tabular}

C - Control containing noodle without seaweed puree or fish meat; T1- noodle with $20 \%$ cooked pangasius fish meat; T2 - noodles with $20 \%$ green seaweed puree; $\mathrm{T} 3$ - noodles with $10 \%$ green sea weed puree and $10 \%$ cooked pangasius fish meat

\section{Proximate composition, crude fibre content and} cooking quality

Moisture, protein, fat, carbohydrate and crude fibre content of the noodles were determined as per standard methods (AOAC, 1990). Cooking time, cooking loss and water absorption were analysed as per AACC (1995).

\section{Sensory analysis}

Descriptive sensory profile of the cooked noodles was assessed by the method described by Bhat and Sharma (1989) with minor modifications. Descriptive sensory profile on firmness, colour, stickiness, roughness and starchy mouth coating were done using a 5 point attribute scale as presented in Table 2. Overall acceptability of the cooked noodles was evaluated to indicate preference on 9 point hedonic scale as described by Amerine et al. (1965), where ' 1 ' represents 'dislike extremely' and '9' represents like extremely.

\section{Texture profile and colour analysis}

Texture profile analysis (TPA) of cooked noodles were conducted with a texture analyser (TA Plus, Lloyd Instruments, Ametek, UK) equipped with a $50 \mathrm{~N}$ load cell. For measuring TPA, 5 strands of cooked noodles were arranged parallel on the measuring platform and compressed twice with cylindrical probe of $10 \mathrm{~mm}$ dia. From the force time curve, parameters such as hardness $(\mathrm{N})$, cohesiveness, springiness $(\mathrm{mm})$, gumminess $(\mathrm{N})$ and chewiness (Nmm), were determined. Colour values viz., L* (lightness), a* (positive value signify red; negative value signify green), $b^{*}$ (positive value signify yellow, negative value signify blue) values were measured using Hunter's colourimeter (ColorFlex EZ, Hunter Lab).

\section{Statistical analysis}

Variations in nutritional and physical properties of noodles were analysed using one way analysis of variance (ANOVA) at 5\% level of significance followed by Tukey's test in Statistical Package for Social Science (SPSS) version 16.0 (IBM).

Table 2. Five point attributes scale for descriptive sensory profile of cooked noodles

\begin{tabular}{llllll}
\hline \multirow{2}{*}{ Sensory parameters } & \multicolumn{5}{c}{ Sensory scores } \\
\cline { 2 - 6 } & 1 & 2 & 3 & 4 & 5 \\
\hline Colour & Light cream & Cream & Light green & Green & Dark green \\
Roughness & Very smooth & Smooth & Slightly rough & Rough & Very rough \\
Firmness & Very soft & Soft & Slightly firm & Firm & Very firm \\
Stickiness & Non sticky & Mildly sticky & Moderately sticky & Sticky & Very sticky \\
Starchy mouth coating & Non starchy & Mildly starchy & Moderately starchy & Starchy & Very starchy \\
\hline
\end{tabular}




\section{Results and discussion}

\section{Proximate composition and crude fibre of noodles}

Proximate composition and crude fibre of different types of noodles were analysed (Table 3). Moisture content of noodles varied from $7.68 \pm 0.11$ to $9.41 \pm 0.06 \%$. Significantly $(p<0.05)$ higher level of moisture content was observed in T2 as compared to other treatments and this might be due to the high water holding capacity of dietary fibre present in seaweed (Gomez-Ordonez, 2010). In addition, the sulfate group located on the surface of polysaccharides will absorb moisture during dough formation. Even though not significant ( $p>0.05)$, moisture content of $\mathrm{T} 3$ was higher than that of $\mathrm{C}$ and $\mathrm{T} 1$. Dewi (2011) also reported that addition of seaweeds powder and puree in noodles increased the moisture content. There was a significant difference $(\mathrm{p}<0.05)$ in protein content of different types of noodles prepared and values ranged from $3.43 \pm 0.39$ to $7.66 \pm 0.48 \%$ dry weight (dw). As expected, higher protein content was found in $\mathrm{T} 1$ i.e., noodles made with $20 \%$ cooked meat of pangasius followed by $\mathrm{T} 3$, where $10 \%$ cooked meat of pangasius was added. Protein content of noodles containing seaweed puree was significantly $(\mathrm{p}<0.05)$ lower to that of $\mathrm{T} 1$ and T3. Protein content decreased in wet noodles when proportion of seaweeds substitution was raised (Yap and Chan, 2001; Dewi, 2011). Addition of pangasius fish mince significantly influenced the fat content of noodles. Highest amount of fat was noticed in noodles with $20 \%$ fish meat (T1) followed by noodles made with $10 \%$ fish meat plus $10 \%$ seaweed puree (T3). Higher fat content in $\mathrm{T} 1$ and $\mathrm{T} 3$ could be attributed to high content of fat in pangasius fish meat (Rao et al., 2013). There was no fat present in control and T2, indicating that the fat content of seaweed and other ingredients used for noodles preparation may be negligible. In general, seaweeds are having very low level of fat (Dawczynski et al., 2007).

Carbohydrate content also varied significantly $(p<0.05)$ between different types of noodles with control having the highest and T1 the lowest carbohydrate content among the samples analysed. Results (Table 3) show that there was a significant $(\mathrm{p}<0.05)$ increase in crude fibre content in noodles incorporated with seaweed puree $(2.62 \pm 0.18 \% \mathrm{dw})$. Similar results were reported by Suryaningrum et al. (2003); Chang and $\mathrm{Wu}$ (2008) and Dewi (2011). Higher amount of dietary fibre in seaweed, can help to lower blood cholesterol levels, reduce the risk of cardiovascular disease and obesity as well as colon cancer (Anderson et al., 2009). In addition, dietary fibre is known to overcome constipation problems and slow down sugar absorption rate that helps to reduce the risk of diabetes (Brownlee, 2011).

\section{Cooking quality of noodles}

Cooking time for noodles varied from 6:80 \pm 0.71 to $9: 15 \pm 0.21 \mathrm{~min}$, without any significant difference between the different types of noodles prepared during the present study (Table 4). Cooking time optimised in our study was comparable or lower to those reported for branded noodles (9:3 min, Vijayakumar et al., 2010). Cooking loss is a measure of the amount of solids lost into the cooking water and considered as a vital indicator of overall cooking performance of noodles by manufacturers and consumers. Cooking loss (\%) was significantly higher for noodles with $20 \%$ seaweed puree $(10.93 \pm 0.85 \%)$ followed by those containing $10 \%$ seaweed puree (Table 4). Similar results have been reported by Prabhasankar et al. (2009) for 30\% seaweed incorporated pasta. Lowest cooking loss was noticed in noodles

Table 3. Nutritional composition of noodles with and without green seaweed puree

\begin{tabular}{llllll}
\hline Noodles & Moisture $(\%)$ & Protein $(\% \mathrm{dw})$ & Carbohydrate $(\% \mathrm{dw})$ & Fat $(\% \mathrm{dw})$ & Crude fibre $(\% \mathrm{dw})$ \\
\hline C & $7.68 \pm 0.11^{\mathrm{a}}$ & $3.43 \pm 0.39^{\mathrm{a}}$ & $61.29 \pm 0.06^{\mathrm{c}}$ & $0.00 \pm 0.00^{\mathrm{a}}$ & $1.50 \pm 0.01^{\mathrm{b}}$ \\
T1 & $7.69 \pm 0.29^{\mathrm{a}}$ & $7.66 \pm 0.48^{\mathrm{c}}$ & $56.94 \pm 0.00^{\mathrm{a}}$ & $0.77 \pm 0.30^{\mathrm{b}}$ & $1.05 \pm 0.00^{\mathrm{a}}$ \\
T2 & $9.41 \pm 0.06^{\mathrm{b}}$ & $3.75 \pm 0.35^{\mathrm{ab}}$ & $57.20 \pm 0.08^{\mathrm{ab}}$ & $0.00 \pm 0.00^{\mathrm{a}}$ & $2.62 \pm 0.18^{\mathrm{c}}$ \\
T3 & $8.37 \pm 0.19^{\mathrm{a}}$ & $5.20 \pm 0.08^{\mathrm{b}}$ & $57.3 \pm 0.08^{\mathrm{b}}$ & $0.37 \pm 0.11^{\mathrm{ab}}$ & $1.71 \pm 0.06^{\mathrm{b}}$ \\
\hline
\end{tabular}

Results are mean \pm SD. Values within a row with different superscript are significantly different $(\mathrm{p}<0.05)$

Table 4. Cooking quality of noodles with and without green seaweed puree

\begin{tabular}{llll}
\hline $\begin{array}{l}\text { Cooking } \\
\text { quality }\end{array}$ & $\begin{array}{l}\text { Cooking time } \\
(\min )\end{array}$ & $\begin{array}{l}\text { Cooking loss } \\
(\%)\end{array}$ & $\begin{array}{l}\text { Water absorption } \\
(\%)\end{array}$ \\
\hline C & $9.15 \pm 0.21^{\mathrm{a}}$ & $9.37 \pm 0.01^{\mathrm{bc}}$ & $311.57 \pm 2.08^{\mathrm{c}}$ \\
$\mathrm{T} 1$ & $7.65 \pm 0.92^{\mathrm{a}}$ & $7.03 \pm 0.42^{\mathrm{a}}$ & $311.92 \pm 0.12^{\mathrm{b}}$ \\
$\mathrm{T} 2$ & $8.00 \pm 0.00^{\mathrm{a}}$ & $10.93 \pm 0.85^{\mathrm{c}}$ & $350.79 \pm 0.71^{\mathrm{d}}$ \\
T3 & $6.80 \pm 0.71^{\mathrm{a}}$ & $8.20 \pm 0.23^{\mathrm{ab}}$ & $289.49 \pm 0.73^{\mathrm{a}}$ \\
\hline
\end{tabular}

Results are mean $\pm \mathrm{SD}$, values within a row with different superscript letters are significantly different $(\mathrm{p}<0.05)$ containing 20\% fish mince, which could be attributed to the binding capacity of myofibrillar protein fractions. Table 4 shows that higher water absorption (\%) was found in noodles with $20 \%$ green seaweed puree $(350.79 \pm 0.71 \%)$ which could be attributed to the water absorption capacity of dietary fibre and polysaccharides. Results of the present study are in agreement with Chang and $\mathrm{Wu}$ (2008) who also observed increase in water absorption capacity in green seaweed incorporated Chinese egg noodles. 
Cooking loss and water absorption differed significantly $(p<0.05)$ but there was no significant difference $(p>0.05)$ of cooking time among different types of noodles.

\section{Colour values and texture profile analysis}

The results showed significant difference $(p<0.05)$ in colour values $\left(\mathrm{L}, \mathrm{a}^{*}\right.$ and $\left.\mathrm{b}^{*}\right)$ of the different types of noodles (Table 5). The L values of noodles significantly $(p<0.05)$ decreased with addition of 10 and $20 \%$ seaweed puree, which indicates decrease in the noodle whiteness. Cooked noodles had lower L values compared to raw noodles, moreover, decrease in $\mathrm{L}$ value in cooked noodles made with $20 \%$ seaweed puree was significantly higher $(\mathrm{p}<0.05)$ than other noodles $(\mathrm{C}, \mathrm{T} 1$ and $\mathrm{T} 3)$. Results indicated that $\mathrm{a}^{*}$ value of noodles with $10 \%$ seaweed puree $(-0.33 \pm 0.03)$ and $20 \%$ seaweed puree $(-1.14 \pm 0.04)$ become significantly greener due to incorporation of green seaweed puree. $\mathrm{a}^{*}$ value of cooked noodles with $20 \%$ seaweed decreased from $-1.14 \pm 0.04$ to $-1.4 \pm 0.02$, whereas, $a^{*}$ remained same for raw and cooked noodles with $10 \%$ seaweed puree. There was significantly $(\mathrm{p}<0.05)$ higher intensity of redness in noodles with $20 \%$ fish meat. Except in T1, yellowness $\left(b^{*}\right)$ of cooked noodles increased as compared to raw noodles in C, T2 and $\mathrm{T} 3$.

Texture profile analysis of noodles indicated that hardness of control noodles was significantly higher than those containing fish mince (Table 6). Addition of seaweed puree reduced the hardness values compared to control. This could be due to the increased water absorption capacity of seaweed incorporated noodles while cooking, resulting in lower force required for compressing the same. Incorporation of fat rich pangasius meat might have negatively affected the hardness of noodles. Lowest hardness was found in seaweed with $10 \%$ seaweed and $10 \%$ fish. There was no significant difference $(\mathrm{p}<0.05)$ in springiness and chewiness value among the different types of noodles.

\section{Sensory evaluation}

Descriptive sensory profile of optimally cooked noodles using a 5 point attribute scale is presented in spider web plot (Fig. 1). Colour of $\mathrm{C}$ and $\mathrm{T} 1$ differed significantly $(\mathrm{p}<0.05)$ from the colour of $\mathrm{T} 2$ and T3. Colour of noodles become greener with increasing concentration of seaweed puree. Both the seaweed incorporated noodles i.e., T2 (4.00 \pm 0.71$)$ and T3 $(3.67 \pm 0.87)$ were found to have green to light green colour while $\mathrm{C}$ and $\mathrm{T} 1$ were light cream to cream in colour, respectively. Sensory score of colour of cooked noodles correlated with L, $\mathrm{a}^{*}$ and $b^{*}$ values measured using Hunter's colourimeter. In terms of roughness, T3 and T2 were found to be smooth to slightly rough because of the presence of grainy particles of seaweeds on noodles surface whereas $\mathrm{C}$ and T1 had smoothness scores of $1.78 \pm 0.67$ and $2.11 \pm 0.78$, respectively which indicates smooth to very smooth surface. Firmness ranged between $1.89 \pm 0.78$ to $2.78 \pm 0.97$ and T2 was found to be slightly firmer as compared to other treatments. In terms of stickiness, T3 (noodles with $10 \%$ fish meat $+10 \%$ seaweed puree) was adjudged to be moderately sticky. However, there was no significant difference among C, T1 and T2. Starchy mouth feel was lower in green seaweed incorporated noodles.

The mean scores of acceptability test of optimally cooked noodles (Fig. 2) demonstrated that control noodles had the highest score in terms of colour and appearance characteristics followed by noodles with $20 \%$ cooked fish meat. Noodles incorporated with $20 \%$ green seaweed

Table 5. Colour values of noodles with and without green seaweed puree

\begin{tabular}{|c|c|c|c|c|c|c|}
\hline \multirow{2}{*}{ Noodles } & \multicolumn{2}{|c|}{ L } & \multicolumn{2}{|c|}{$a^{*}$} & \multicolumn{2}{|c|}{$b^{*}$} \\
\hline & Raw & Cooked & Raw & Cooked & Raw & Cooked \\
\hline $\mathrm{C}$ & $86.18 \pm 0.01^{\mathrm{d}}$ & $74.23 \pm 0.01^{\mathrm{d}}$ & $0.76 \pm 0.0^{c}$ & $0.74 \pm 0.01^{\mathrm{c}}$ & $13.37 \pm 0.25^{\mathrm{a}}$ & $16.07 \pm 0.05^{\mathrm{a}}$ \\
\hline $\mathrm{T} 1$ & $80.54 \pm 0.29^{c}$ & $72.03 \pm 0.03^{\mathrm{c}}$ & $2.13 \pm 0.13^{\mathrm{d}}$ & $1.75 \pm 0.01^{\mathrm{d}}$ & $18.05 \pm 0.02^{\mathrm{b}}$ & $18.41 \pm 0.00^{b}$ \\
\hline $\mathrm{T} 2$ & $74.00 \pm 0.04^{\mathrm{a}}$ & $58.67 \pm 0.04^{\mathrm{a}}$ & $-1.14 \pm 0.04^{\mathrm{a}}$ & $-1.4 \pm 0.02^{\mathrm{a}}$ & $19.66 \pm 0.13^{\mathrm{c}}$ & $23.40 \pm 0.14^{\mathrm{d}}$ \\
\hline $\mathrm{T} 3$ & $78.88 \pm 0.14^{b}$ & $66.15 \pm 0.07^{\mathrm{b}}$ & $-0.33 \pm 0.03^{b}$ & $-0.3 \pm 0.01^{b}$ & $18.45 \pm 0.01^{\mathrm{b}}$ & $22.89 \pm 0.01^{\mathrm{c}}$ \\
\hline
\end{tabular}

Results are mean $\pm \mathrm{SD}$, values within a row with different superscript letters are significantly different $(\mathrm{p}<0.05)$

Table 6. Textural profile analysis of noodles with and without green seaweed puree

\begin{tabular}{lllll}
\hline Noodles & Hardness $(\mathrm{N})$ & Cohesiveness & Springiness $(\mathrm{mm})$ & Gumminess $(\mathrm{N})$ \\
\hline C & $18.19 \pm 1.40^{\mathrm{b}}$ & $0.06 \pm 0.01^{\mathrm{b}}$ & $0.69 \pm 0.03^{\mathrm{a}}$ & $0.89 \pm 0.25^{\mathrm{b}}$ \\
T1 & $11.21 \pm 0.99^{\mathrm{a}}$ & $0.02 \pm 0.01^{\mathrm{a}}$ & $0.34 \pm 0.10^{\mathrm{a}}$ & $0.17 \pm 0.08^{\mathrm{a}}$ \\
T2 & $15.54 \pm 0.88^{\mathrm{b}}$ & $0.04 \pm 0.01^{\mathrm{ab}}$ & $0.32 \pm 0.35^{\mathrm{a}}$ & $0.06 \pm 0.04^{\mathrm{a}}$ \\
T3 & $10.44 \pm 0.77^{\mathrm{a}}$ & $0.03 \pm 0.01^{\mathrm{ab}}$ & $0.49 \pm 0.08^{\mathrm{a}}$ & $0.23^{\mathrm{ab}}$ \\
\hline
\end{tabular}

Results are mean \pm standard deviation. Values within a row with different superscript letters are significantly different ( $\mathrm{p}<0.05$ ) 


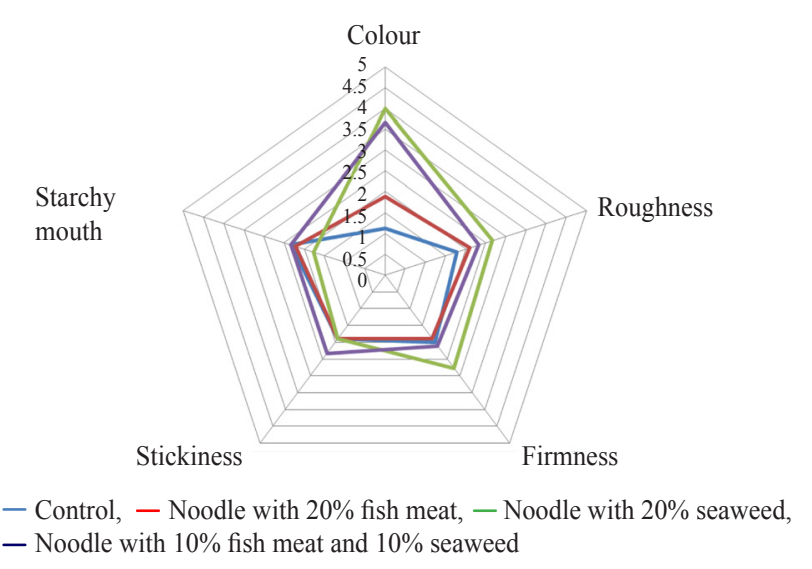

Fig. 1. Descriptive sensory profile of optimally cooked noodles

puree showed the lowest score for colour property. However, the noodles containing $20 \%$ seaweed puree had the highest score in relation to flavour attribute and taste.

Results of the present study revealed that incorporation of green seaweed ( $U$. reticulata) puree increased the moisture, crude fibre content and water holding capacity of noodles. Moreover, addition of seaweed did not negatively influence the textural properties of cooked noodles. Noodles containing $20 \% \mathrm{w} / \mathrm{w}$ green seaweed puree was considered as acceptable in terms of flavour attribute and taste. Addition of fish mince also demonstrated a positive effect on the nutritional properties of noodles, with minimum alteration on textural and cooking attributes. In brief, the study indicated that $U$. reticulata and pangasius fish mince can be considered as potential ingredients for developing healthy noodles products.

\section{Acknowledgements}

We thank Dr. Ravishankar, C. N., Director, ICAR-CIFT, Kochi for the encouragement and guidance. Technical assistance rendered by M. Prasanna Kumar and G. Bhushanam is gratefully acknowledged.

\section{References}

AACC 1995. Laboratory methods, $10^{\text {th }}$ edn. American Association of Cereal Chemists, St. Paul, MN, USA.

Amerine, M. A., Pongborn, R. H. and Roescler, E. B. 1965. Principles of sensory evaluation of food. Academic Press, New York, 602 pp.

Anderson, J. W., Baird, P., Davis, J. R. H., Ferreri, S., Knudtson, M. and Koraym, A. 2009. Health benefits of dietary fibre. Nutr. Rev., 67: 188-205.

AOAC 1990. Official methods of analysis, $15^{\text {th }}$ edn. Association of Official Analytical Chemists, Washington, DC, USA.

Bhat, G. T. C. M. and Sharma, K. 1989. Organoleptic evaluation of nutritious dhal vadas. J. Agricul. Res., 26: 334-338.

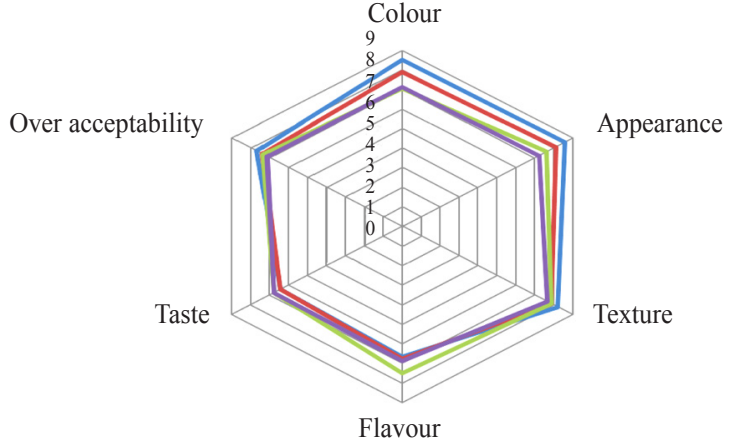

- Control, - Noodle with $20 \%$ fish meat, - Noodle with $20 \%$ seaweed, — Noodle with $10 \%$ fish meat and $10 \%$ seaweed

Fig. 2. Overall acceptability of optimally cooked noodles

Bocanegra, A., Bastida, S., Benedi, J., Rodenas, S. and SanchezMuniz, F. J. 2009. Characteristics and nutritional and cardiovascular-health properties of seaweeds. J. Med. Food, 12(2): 236-258.

Brownlee, I. A. 2011. The physiological roles of dietary fibre. Food Hydrocoll., 25: 238-250.

Chang, H. C. and Wu, L. C. 2008. Texture and quality properties of Chinese fresh egg noodles formulated with green seaweed (Monostroma nitidum) powder. J. Food Sci., 73: 398-404.

Dawczynski, C., Schubert, R. and Jahreis, G. 2007. Amino acids, fatty acids and dietary fibre in edible seaweed products. Food Chem., 103: 891-899.

Dewi, E. N. 2011. Quality evaluation of dried noodle with seaweeds puree substitution. J. Coast. Develop., 14(2): 151-158.

Fleurence, J. 1999. Seaweed proteins: Biochemical, nutritional aspects and potential uses. Trend. Food Sci. Technol., 10: $25-28$.

Gomez-Ordonez, E., Jimenez-Escrig, A. and Ruperez, P. 2010. Dietary fibre and physicochemical properties of several edible seaweeds from the north-western Spanish coast. Food Res. Int., 43: 2289-2294.

Goni, I., Valdivieso, L. and Garcia-Alonso, A. 2000. Nori seaweed consumption modifies glycemic response in healthy volunteers. Nutr. Res., 20: 1367-1375.

Gupta, S. and Abu-Ghannam, N. 2011. Bioactive potential and possible health effects of edible brown seaweeds. Trend. Food Sci. Technol., 22: 315-326.

Gupta, S., Rajauria, G. and Abu-Ghannam, N. 2010. Study of the microbial diversity and antimicrobial properties of Irish edible brown seaweeds. Int. J. Food Sci. Technol., 45: 482-489.

Kim, Y., Kee, J. I., Lee, S. and Yoo, S. H. 2014. Quality improvement of rice noodle restructured with rice protein isolate and transglutaminase. Food Chem., 146: 409-416. 
Kuda, T., Tsunekawa, M., Hishi, T. and Araki, Y. 2005. Antioxidant properties of dried 'kayamo-nori', a brown alga Scytosiphon lomentaria (Scytosiphonales, Phaeophyceae). Food Chem., 89: 617-622.

Ojure, M. A. and Quadri, J. A. 2012. Quality evaluation of noodles produced from unripe plantain flour using Xanthan gum. Int. J. Res. Rev. Appl. Sci., 13(3): 740-752.

Prabhasankar, P., Ganesan, P., Bhaskar, N., Hirose, A., Nimishmol Stephen., Gowda, L. R., Hosokawa, M. and Miyashita, K. 2009. Edible Japanese seaweed, wakame (Undaria pinnatifida) as an ingredient in pasta: Chemical, functional and structural evaluation. Food Chem., 115: 501-508.

Rao, B. M., Murthy, L. N. and Prasad, M. M. 2013. Shelf life of chill stored pangasius (Pangasianodon hypophthalmus) fish fillets: Effect of vacuum and polyphosphate. Indian $J$. Fish., 60(4): 93-98.

Ruperez, P., Ahrazem, O. and Leal, J. A. 2002. Potential antioxidant capacity of sulfated polysaccharides from the edible marine brown seaweed Fucus vesiculosus. J. Agric. Food Chem., 50(4): 840-845.

Silva, J. L., Kim, T. and Danviriyakul, S. 2002. Development of food products from channel catfish byproducts.
In: Bechtel, P. J. (Ed.), Advances in seafood byproducts. 2002. Conference proceedings, Alaska Sea Grant College Program, University of Alaska, Fairbanks, p. 343-349.

Suryaningrum, T. D., Murtini and Erlina, M. D. 2003. Pengaruh Perlakuan Alkali dan Volume Larutan Pengekstrak Terhadap Mutu Karaginandari Rumput Laut. J. Penelitian Pasca Panen Perikanan, 9(5): 65-76.

Verardo, V., Ferioli, F., Riciputi, Y., Iafelice, G., Marconi, E. and Caboni, M. F. 2009. Evaluation of lipid oxidation in spaghetti pasta enriched with long chain n-3 polyunsaturated fatty acids under different storage conditions. Food Chem., 114: 472-477.

Vijayakumar, T. P., Mohankumar, J. B. and Srinivasan, T. 2010. Quality evaluation of noodles from millet flour blend incorporated composite flour. J. Sci. Ind. Res., 69: 48-54.

World Instant Noodle Association 2014. Expanding market. https:/instantnoodles.org/noodles/expanding-market.html (Accessed 30 August 2014).

Yap, C. Y. and Chen 2001. Polyunsaturated fatty acid: Biological significance of biosynthesis and production by macroalgae and microalgae like organism. In: Feng Chen and Yue Jiang (Eds.), Algae and their biotechnological potential, Kluwer Academic Publisher, p. 1-32. 